\title{
Frequência da deficiência de glicose-6-fosfato desidrogenase (G-6-PD) e sua relação com a icterícia neonatal
}

\author{
Frequency of glucose-6-phosphate dehydrogenase deficiency (G-6-PD) and its relationship with \\ neonatal jaundice
}

\author{
Marli Auxiliadora C. Iglessias \\ Orientadora: Tereza Maria D. Medeiros
}

\section{Resumo}

A deficiência de glicose-6-fosfato desidrogenase (G-6-PD) é a eritroenzimopatia mais comum, e as principais manifestações clínicas são hemólise induzida por fármacos e icterícia neonatal. $\mathrm{O}$ presente estudo teve como objetivo principal investigar a frequência da deficiência de glicose-6-fosfato desidrogenase em recém-nascidos e verificar a sua relação com a icterícia neonatal. Foram examinadas 450 amostras de sangue de recém-nascidos, sendo 400 de sangue de cordão umbilical (Grupo I) e 50 de sangue venoso de recém-nascidos a termo, com icterícia na primeira semana de vida (Grupo II), provenientes de unidades hospitalares da cidade do Natal. Todas as amostras foram analisadas mediante o teste de redução da metahemoglobina (teste de Brewer). Os casos deficientes foram confirmados pela determinação quantitativa da atividade enzimática e eletroforese em acetato de celulose para verificar o tipo de variante. Foram diagnosticados 8 deficientes de G-6PD entre as 400 amostras de sangue de cordão umbilical, correspondendo a uma frequência de $2 \%$. Entre os recém-nascidos do sexo masculino a frequência foi de $3,9 \%$, não sendo diagnosticado nenhum deficiente entre os recém-nascidos do sexo feminino. Quatro recém-nascidos deficientes $(50 \%)$ apresentaram icterícia cujo início ocorreu durante as primeiras 48 horas de vida. Todos desenvolveram icterícia moderada apresentando níveis de bilirrubina superiores a 10,0 mg/dL. Entre os 50 recém-nascidos com icterícia na primeira semana de vida, a frequência da deficiência de G-6-PD foi de $8 \%(4 / 50)$. Todos os recém-nascidos deficientes (Grupos I e II) apresentaram a variante Africana (G6PD A-). Os resultados do estudo comprovam a existência da associação entre a deficiência de G-6-PD e a icterícia neonatal. Portanto, o diagnóstico precoce da deficiência é importante para o controle do surgimento da icterícia e para prevenir a exposição destes recém-nascidos a agentes desencadeantes de hemólise.

Palavras-chave: Deficiência de G-6-PD; recém-nascidos; icterícia neonatal.

\begin{abstract}
Glucose-6-phosphate dehydrogenase (G-6-PD) deficiency is the most common enzyme deficiency with its main clinical manifestations being hemolysis induced by drugs and neonatal jaundice. The aim of this study was to investigate the frequency of G-6-PD deficiency in newborns and verify its relationship with neonatal jaundice. A total of 450 blood samples of full-term newborns that presented with jaundice within the first week of life were analyzed, including 400 umbilical cord blood samples (Group I) and 50 peripheral blood samples (Group II). All of them originated from Public Healthcare Clinics of Natal, Rio Grande do Norte, Brazil. The methemoglobin reduction test (Brewer's test) was carried out for all blood samples. Deficiency was confirmed by quantitative spectrophotometric assay for enzyme activity and cellulose acetate electrophoresis in order to assess the G-6-PD variant. Eight G-6-PD deficient individuals were diagnosed among the 400 cord blood samples giving a frequency of $2 \%$. Among boys, the frequency was $3.9 \%$ but no deficient girls were identified. Four neonates (50\%) with G-6-PD deficiency suffered jaundice within the first 48 hours of life. All of them developed moderate jaundice showing bilirubin levels higher than $10.0 \mathrm{mg} / \mathrm{dL}$. Of the 50 newborns that presented with jaundice in the first week of life, the frequency of G-6-PD deficiency was $8 \%$ (4/50). All G-6-PD-deficient neonates (Groups I and II) had an African variant (G6PD A-). The results of this study confirmed the association between G-6-PD deficiency and neonatal jaundice. Precocious diagnosis of the deficiency through neonatal screening is essential to control jaundice and to prevent exposure of these newborns to known hemolytic agents.
\end{abstract}

Key words: G-6-PD deficiency; newborns; neonatal jaundice.

Suporte Financeiro: CNPq; Fapern e Fapam/UFRN.

Avaliação: A RBHH publica os resumos e abstracts de teses da área apresentados em entidades que tenham programas de pós-graduação reconhecidos pelo $\mathrm{MEC/Capes} \mathrm{e} \mathrm{considera} \mathrm{a} \mathrm{obtenção} \mathrm{do} \mathrm{título}$ suficiente para sua publicação na forma como se propõe a seção.

Recebido: 15/09/2008; Aceito: 16/09/2008

Tese de dissertação para obtenção do titulo de Mestre em Ciências Farmacêuticas apresentada à UFRGN - Natal.

Correspondência: Tereza Maria Dantas de Medeiros

Centro de Ciências da Saúde - Depto. de Análises Clínicas e Toxicológicas - Universidade Federal do Rio Grande do Norte

Rua General Gustavo Cordeiro de Farias, $s / n-1^{\circ}$ andar - Petrópolis

59010-180 - Natal-RN - Brasil

Email: tdantas@ufrnet.br 